This document is a manuscript version of the following article:

Title: Key factors for successful leisure and tourism public transport provision

By: Gronau, Werner; Kagermeier, Andreas

Published in: Journal of Transport Geography, Volume 15, Issue 2,

March 2007, Pages 127-135

Publisher: Elsevier | Year: 2007

DOI: 10.1016/j.jtrangeo.2006.12.008

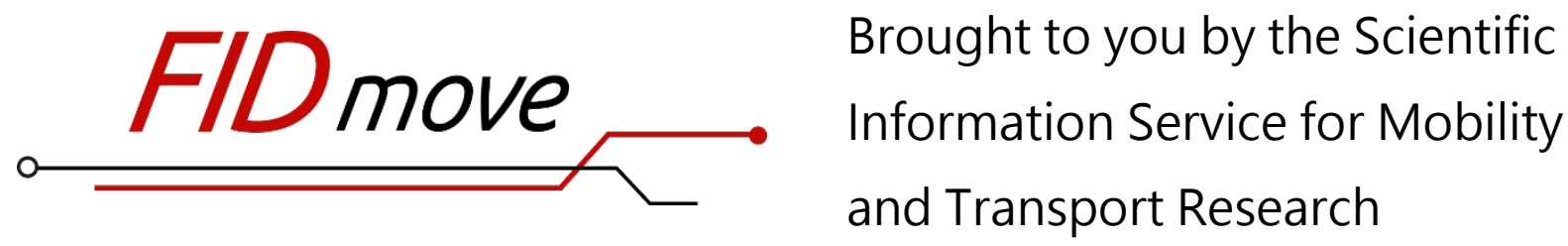

Fachinformationsdienst Mobilitäts- und Verkehrsforschung

Website: www.fid-move.de

Repository: publish.fid-move.de

Contact: publish@fid-move.de

(C) 2007. This manuscript version is made available under the CC-BYNC-ND 4.0 license.

http://creativecommons.org/licenses/by-nc-nd/4.0/ 


\title{
Key factors for successful leisure and tourism public transport provision
}

\author{
Werner Gronau ${ }^{\mathrm{a}, 1}$, Andreas Kagermeier ${ }^{\mathrm{b}, *}$ \\ ${ }^{a}$ Intercollege Larnaca, 1 Pavlou Street, CY-6500 Larnaca, Cyprus \\ ${ }^{\mathrm{b}}$ Department of Geography, University of Trier, Campus II-Behringstr, D-54286 Trier, Germany
}

\begin{abstract}
In the second half of the 20th century, the main focus of transport policy and transport studies was on the reduction of the use of motorised, individual transport, in particular with regard to daily commuter traffic. The main concepts concentrated on creating an attractive public transport supply and, where possible, improving the infrastructure for non-motorized traffic in order to open up alternative forms of travel. Although these concepts produced noticeable effects on everyday travel, they could not cope with steadily rising problems in the field of leisure traffic. Therefore, primarily supply oriented, autocratic desktop transport policies cannot be seen as a promising approach within the leisure context.

Consequently, the article focuses on the necessary key factors for successful leisure and tourism public transport provision. It stresses the need for rethinking transport policy by choosing a demand oriented approach and realising the importance of additional accompanying efforts in the areas of marketing, transparency and quality. Focusing on the demand side, with its individual attitudes and preferences, leads to a new understanding of traffic planning by adopting a bottom up, rather than a top down approach.
\end{abstract}

(C) 2007 Elsevier Ltd. All rights reserved.

Keywords: Leisure; Tourism; Public transport; Success factors; Germany; Mobility

\section{Introduction}

In spite of leisure's high share of today's traffic, the use of public transport within this segment is rather low. This might be explained by the fact that key factors such as fares, quality of service, income and car ownership, which influence everyday transport demand (see Paulley et al., 2006) are not that relevant within the context of leisure mobility. A more relevant approach to determining the use of public transport in leisure time can be identified from a number of interesting qualitative research activities, concerning different mobility patterns (see for example Gärling et al., 1998; Hunecke et al., 2001; Heath and Gifford, 2002; Freitag and Kagermeier, 2002; Bamberg, 2004). However, these qualitative findings have not yet been sufficiently con-

\footnotetext{
* Corresponding author. Tel.: +49 651201 4582; fax: +496512013813.

E-mail addresses: gronau.w@ihs-intercollege.ac.cy (W. Gronau), andreas@kagermeier.de (A. Kagermeier).

${ }^{1}$ Tel.: +357 24 653438; fax: +35724652213.
}

sidered when it comes to influencing travel behaviour. Therefore, this article aims to transfer scientific research results into a practical course of action, in order to influence the decision-making process with regard to different transport alternatives in leisure time. It will provide a number of necessary conditions for implementing new, attractive public transport supply in the field of leisure and tourism.

The article commences with a short overview of the two main clichés concerning leisure and tourism travel. The important role of the demand side, demonstrated by numerous qualitative findings, is then stressed. Finally, additional specific supply conditions for implementing successful public transport services in leisure time, determined by the afore mentioned demand orientation, will be discussed.

\section{Clichés surrounding public transport in leisure time}

When talking about mobility in leisure time, one has to first of all realise that the picture is often clouded by 


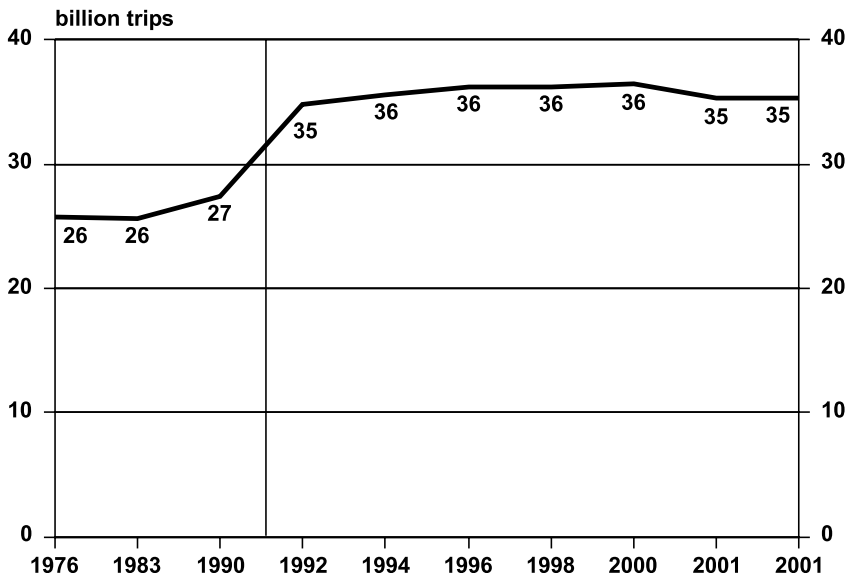

Fig. 1. Number or trips for leisure and tourism purposes in Germany. Source: BMVBW (2003).

numerous, typical clichés, which need to be disposed of before further discussion on the subject. Gstalter (2003), for example, gives an interesting overview. He first of all refers to cliché that leisure and tourism traffic is a fast-growing market, which knows no signs of saturation. As data from Germany on the number of leisure and tourism trips show, this is no longer true: from the mid 1970s up to reunification the figure remained quite stable. Following German reunification there was, of course, a significant increase. After this boost the numbers once again reflected a quite stable situation (see. Fig. 1). By contrast, when focussing on recent years, one can identify a slight decline (see Gstalter, 2003, p. 105).

The impression that leisure and tourism traffic has grown refers not to the number of trips, but to the distances covered by these trips. Growing distances are a common fact of transport science, due to higher degrees of motorization and the increasing use of motorized vehicles. Nevertheless the growth has been above average in the field of leisure and tourism traffic where the increased use of aircraft in particular has for a long time lead to a significant rise in passenger kilometres travelled per year. However, since the mid 1990s, even the distances covered for leisure and tourism purposes are stagnating in Germany, showing a slight sign of regression in recent years (Fig. 2). Thus, even the rise of the so-called low cost carriers in the last years did not lead to a significant rise in the overall distance travelled.

A further common perception is that leisure and tourism traffic is a segment of the transport market which has a high affinity for motorized private vehicles (see Gather and Kagermeier, 2002). This notion can be easily confirmed by referring to empirical data from Germany (Fig. 3). More than half of the trips undertaken for leisure and tourism purposes are by motorized individual vehicle. Public transport has a share of only $5 \%$, whereas more than a third of the trips (almost exclusively for leisure purposes) are nonmotorized. With regard to distance, the preponderance of private owned cars is still overwhelming: three quarters of total kilometres travelled are by car. Due to the shorter distances of walking and bicycle trips, the share of non-motor-

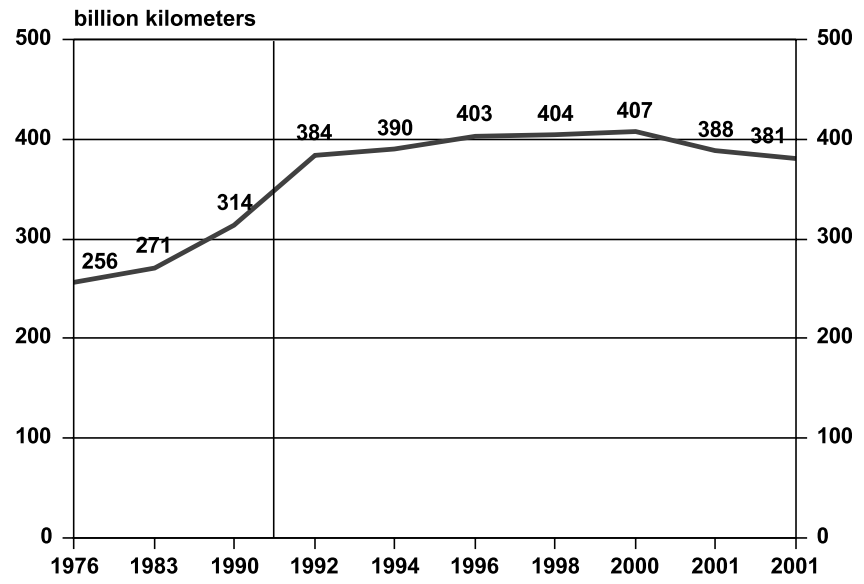

Fig. 2. Distances for leisure and tourism purposes in Germany. Source: BMVBW (2003).

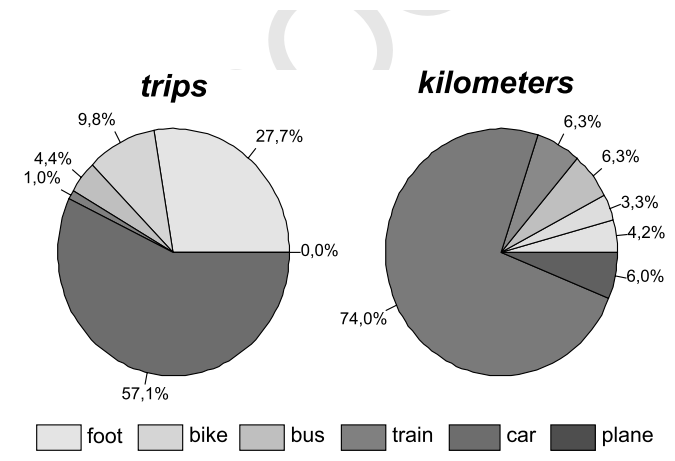

Fig. 3. Modal split for leisure and tourism purposes in Germany. Source: BMVBW (2003).

ized modes remains quite small. The opposite is true for airplane trips which are small in number but cover a share of $6 \%$ of the distance. Terrestrial public transport is used for about $12 \%$ of total kilometres travelled (see BMVBW, 2003).

To sum up, the notion of leisure and tourism traffic as a steadily growing segment cannot be proven with the existing data, rather the data shows a slight decline. When discussing the role of public transport in leisure and tourism traffic, one has to consider that the initial position for public transport provision in the leisure and tourism market segment is of course marked by the strong position of the main competitor, the private car. Nevertheless this can be seen as a challenge to take a larger "piece of the cake".

\section{Necessary conditions on the demand side for successful public transport provision}

As stressed in various other contexts, customer orientation is a crucial aspect when trying to elaborate transport supply for leisure purposes in tourism regions. This line-ofaction recognizes the pre-conditions of travel behaviour on the whole. As a result the article stresses the influence of individual attitudes and standards towards more sustainable travel behaviour. It must be realised that these attitudes are more often the cause for not using public 
115

116 transport in leisure time than the public transport supply itself.

\subsection{The image of public transport in the context of leisure}

In exploring this aspect, it is useful to turn to the findings of psychology colleagues. When a representative sample of the German population was asked to what degree they associate modes of transport with leisure time, the findings clearly showed that there is a substantial difference in the association of different transport alternatives with leisure (see Fig. 4). It is unsurprising that bicycle, boat and airplane show a high degree of association with leisure time, but Fig. 4 also indicates that public transport shows a significantly lower connection with leisure travel than the competitor car, respectively, sports car (see Fastenmeier et al., 2001). Taking into account that these associations also have an influence on everyday behaviour, it is important to find out more about the factors that underpin this low association of public transport with leisure time.

\subsection{The role of the fun and function factors}

Several empirical studies undertaken in Germany identified the aspects of fun and function as the most important ones in judging transport alternatives for leisure time. Taking these findings into consideration, it is possible to construct seven, life-style-oriented, so-called "Mobility Groups", defined according to similarities in their rationale for choosing a transport alternative in leisure time (see Lanzendorf, 2001). The construction of these groups is based on a household-survey of 2000 persons. The Mobility Groups were created as a result of cluster analysis using a wide variety of different indicators for respondents' leisure interests, but also for their preferences towards a transport alternative in leisure time. Examining these groups can assist in gaining an idea of the reasons for the low leisure connotation of public transport.

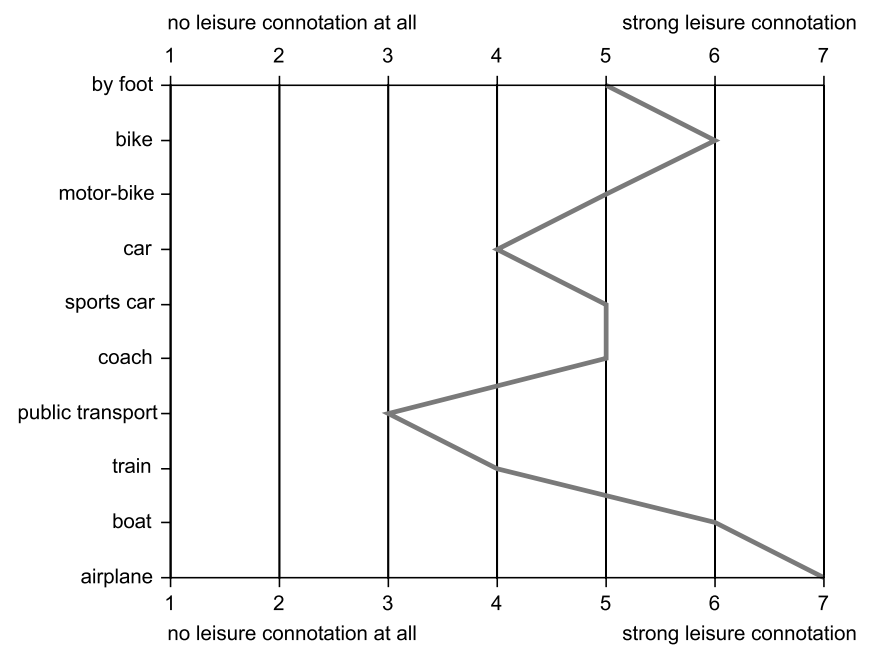

Fig. 4. Leisure connotation of different means of transport. Source: Fastenmeier et al. (2001).

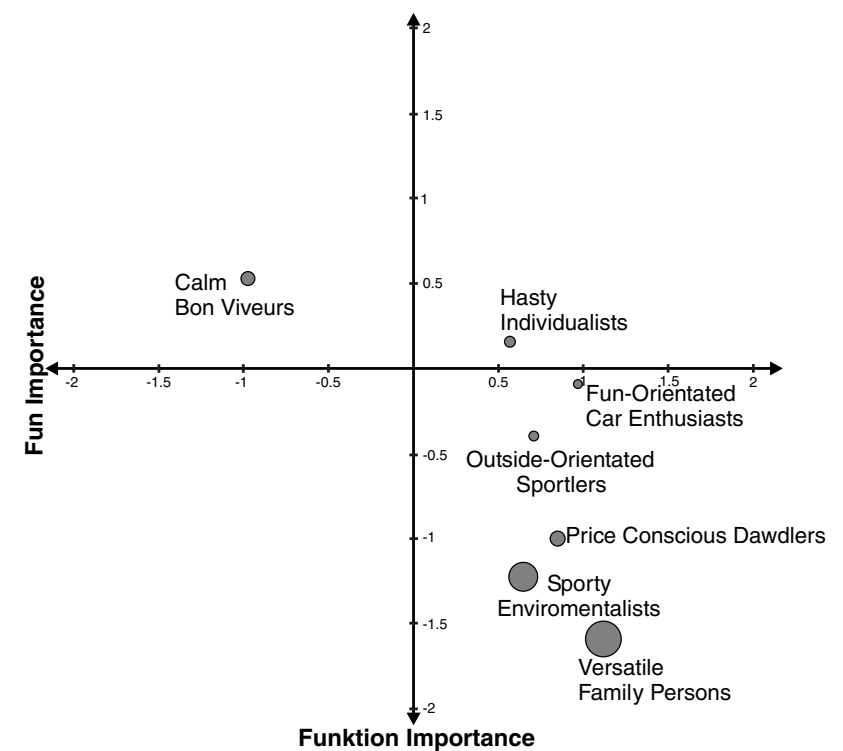

Fig. 5. Importance of fun and function for transport alternatives in leisure time by, "Mobility Groups". Source: Gronau (2004).

Fig. 5 shows the different Mobility Groups within a system of co-ordinates illustrating their perception of the importance of fun and function when choosing a transport alternative. With reference to the 5 grade rating-scale, there is a range from -2 to +2 , where the $x$-axis shows the factor "Function" and the $y$-axis the factor "Fun". It becomes clear that, in leisure time, the factor function has the greatest influence on choosing a transport mode but, for certain groups, the factor fun also plays an important role (see Gronau, 2005). It is possible to reduce the Mobility Groups to just three specific types:

- The first type emphasises only the factor "Function" when it comes to choosing a transport alternative in leisure time;

- The second type more or less balances the two factors out; and

- The third type consists of just one group, clearly prioritising the factor fun.

The sizes of the different circles within Fig. 5, which indicate the size of each group, show that groups belonging to the first type represent a clear majority.

By accepting the different emphasis of the main factors fun and function in each of the groups, a closer look at the association of every group with the transport alternatives car (light grey colour) and public transport (black colour) partially explains the differences between these two transport alternatives (Fig. 6). All groups emphasise the lack of the function factor for public transport compared to the car but, with reference to the fun factor, the two alternatives are quite similar for most of the groups. Thus the low overall association is mainly caused by the weak influence of the function factor with regard to public transport use in leisure time. Just two groups, containing a very small number 


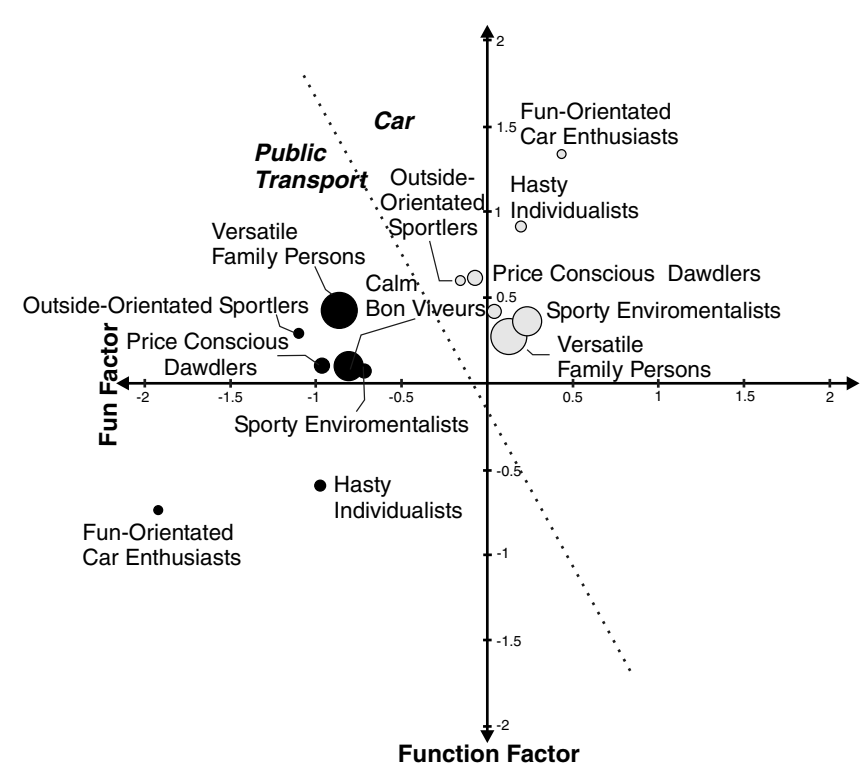

Fig. 6. Connotations for different transport alternatives in leisure time by, "Mobility Groups". Source: Gronau (2004).

of persons, assume public transport is also less competitive 183 regarding the fun factor.

\subsection{The concept of affinity towards different modes of transport}

Following on from the above discussion, one can estimate a certain affinity for every group with regard to the transport alternatives car and public transport, meaning that it is possible, to a certain extent, to forecast probable use of the two alternatives (see Gronau, 2005). This socalled affinity is based, on one hand, on the importance of the factors and, on the other hand, on perceptions of the transport alternatives. Therefore, the results are mainly based on perceptions of the extent to which the given transport alternative will perform satisfactorily on these factors. The system of co-ordinates shows a clear affinity towards the use of the private car for all identified groups (Fig. 7) but, for the majority of the groups, the affinity towards the private car is not overwhelming and, by taking into consideration the lack of the function factor it is arguable that, given an improvement in public transport provision, the affinity could almost be the same towards both alternatives. Two of the groups, however, show a strong resistance towards public transport use and it is likely that even a highly improved system would not be a real alternative to the private car for these groups.

In order to test the above theories in the context of real life situations, an empirical study was performed on eight different leisure facilities to identify these mobility groups and their specific modal-split. The first chosen example illustrates the situation at the zoo in Munich. Fig. 8 shows the individual modal-split of three different mobility groups at the same location at the same time. The only difference between the groups is their affinity towards different trans-

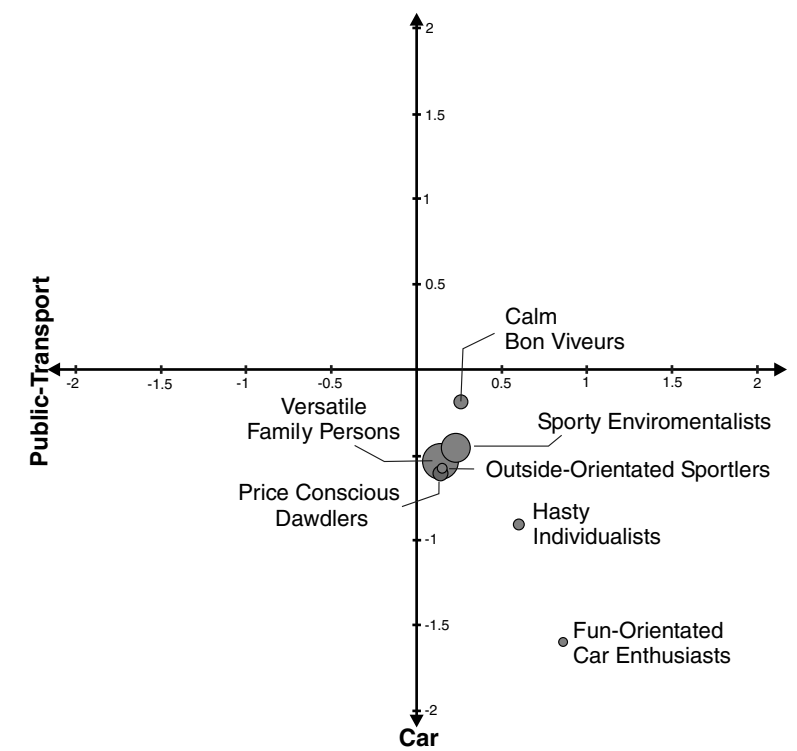

Fig. 7. Affinity for different transport alternatives in leisure time by, "Mobility Groups". Source: Gronau (2004).

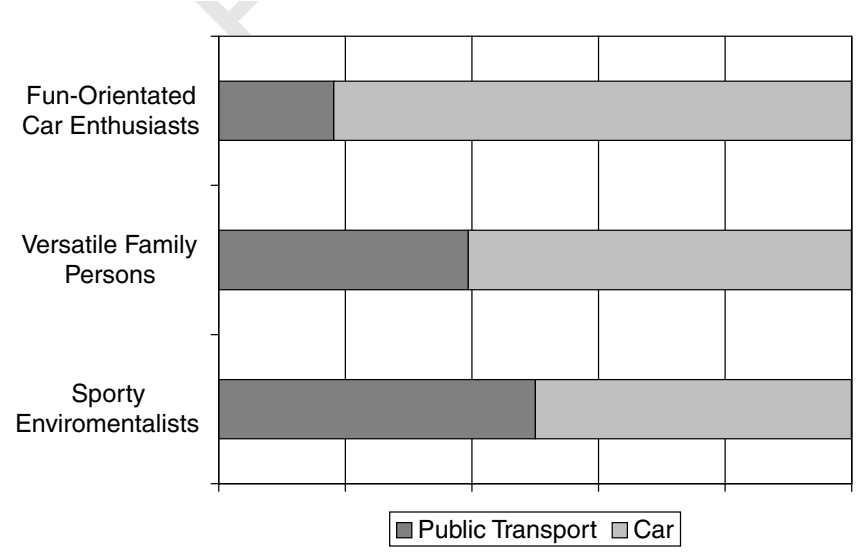

Fig. 8. Influence of "Mobility Groups" I: (Location Zoo Munich). Source: Gronau (2004).

port alternatives. The figure shows a clear difference between these groups, with reference to their affinity. The use of public transport is almost twice as high for "Sporty Environmentalists" as it is for "Fun-Orientated Car Enthusiasts".

Similarly, Fig. 9 shows the same groups at a different location, a large thermal spa destination with poor public transport provision. The results back up the findings for the previous sample. Although the overall level of public transport use is much lower, the ranking of the groups remains the same and the differences between the groups become even bigger, stressing the role of the specific affinities. The extra time cost of the trip caused by poor supply and the possible additional need for timetable information is only tolerated by people having a clear affinity towards public transport. This selective effect in the use of public transport with reference to the different groups and their specific affinity can be identified in different intensities but is still significant for all groups at almost all other locations. Thus, 


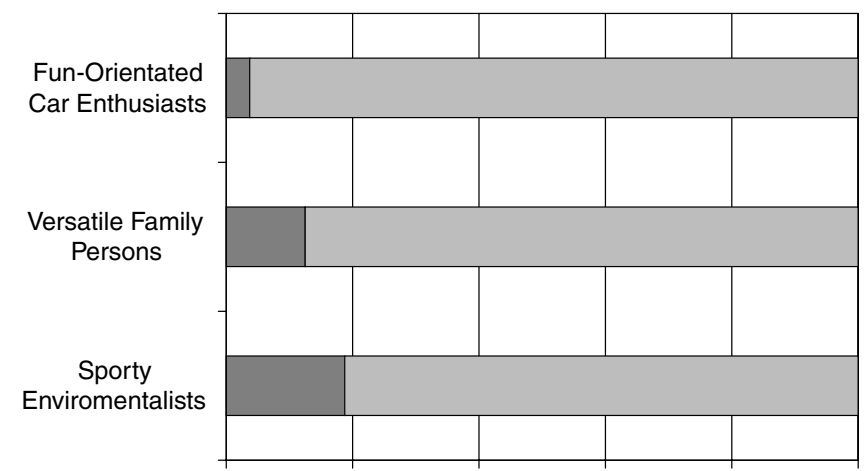

$\square$ Public Transport $\square$ Car

Fig. 9. Influence of "Mobility Groups" II: (Location Therme Erding) Source: Gronau (2004). it can be concluded that the empirical study clearly proent transport alternatives and the perception of people towards the alternatives. At the same time, however, it clearly showed that, notwithstanding the two groups who show no likelihood of becoming public transport users, for the majority of the groups the function factor in particular needs to improve in order to raise public transport use. Finally, the study suggests that, where services are perceived to be adequate, there is clear potential for public transport use in leisure time.

\section{Necessary conditions on the supply side for successful public transport services}

Thus far the paper has shown clear potential for public transport use in leisure time based on the attitudes of users. At the same time public transport plays only a marginal role in the field of leisure mobility. This leads to further questions on which particular conditions need to be changed in order to achieve a greater share of the market?

\subsection{Transparency and quality of the public transport service}

One essential structural pre-condition which is often is not properly taken into account is the fact that - contrary to everyday traffic - there is a greater element of choice in selecting between different transport opportunities for leisure and tourism traffic. Heinze and Kill (1997) stress that the principle of freedom of choice, when it comes to customer transport alternatives in the field of leisure traffic, has crucial implications for the quality and transparency of transport services. The obvious basic condition is therefore that a company should not try to enter the market unless it cannot provide a high quality level of service (Kagermeier, 2002). This applies not only to the frequency with which a destination is served, but also to appropriate routings, minimising the necessity to change busses or trains. Furthermore, with regard to the quality level of public transport supply, a second, very closely related, basic condition vides evidence for the interdependency of the use of differ-

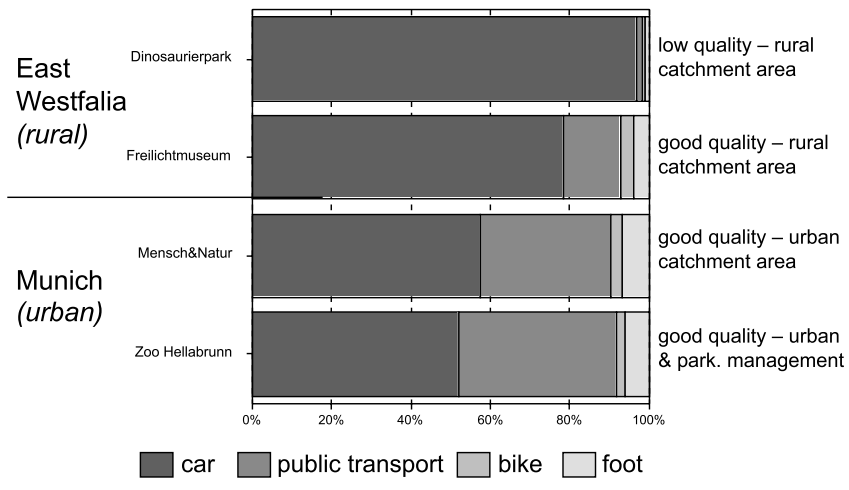

Fig. 10. Modal split in different edutainment facilities. Source: own investigation.

must be taken into account, namely whether the level service is homogenous across the whole catchment area. It is not enough to provide high quality services only for the famous "last mile" leading to a destination or leisure facility, one has to look at the whole transport-chain starting with the journey from the customers' home. A high-quality supply of public transport must be provided on the entire route between the customers' home and the destination. The following empirical evidence underlines this fact.

Within the context of a study done for the Deutsche Forschungsgemeinschaft (DFG), visitors to four leisure parks, which can be characterized as edutainment facilities mainly aiming at the same target group (i.e. families with children), were questioned. Two of these facilities attract mainly customers from rural areas and two of them, situated right in the centre of the metropolitan area of Munich, attract mainly residents of the metropolitan area. Apart from these regional differences, the institutions are very similar, since the catchment area has a comparable size of about $90 \mathrm{~min}$ at all four facilities. The first example, the Dinsoaurier-Park, is insufficiently accessible by public transport, since it is serviced with a mere four buses per day. Thus, it is unsurprising that virtually no one uses public transport to visit the park (see Fig. 10). The second example an open-air museum - is linked to the high quality city bus system of the medium sized town of Detmold and is minimally served about every half an hour. This is enough to attract about $15 \%$ of the visitors to public transport. Since it is quite difficult to reach Detmold by train, most people coming from the surrounding villages and towns in the region still use their own car. The third example in the metropolitan area of Munich has a comparable service level to Detmold, but most visitors come from places that are served by metropolitan trains (which run about twice an hour). Here almost one third of the visitors travelled by train and bus to reach the leisure facility Mensch \& Natur. The clear increase in the number of people using public transport in relation to the increased frequency of public transport provision in the areas the people come from provides empirical evidence for the importance of good public transport supply over the entire distance between the customers' home and the destination. 


\section{4.2. Restricting use of the private car}

\section{3}

314

315

316

317

318

319

320

321

322

323

324

325

326

327

328

329

330

331

332

333

334
Of course, the quality of public transport is not an isolated factor and is always related to the accessibility of the destination by the private car. Hence, influencing accessibility by car might be a possible solution to improving the share of public transport. Of course when talking about restrictions on the private car, there has to be a clear monitoring of the impacts and the opportunity for customers to switch to public transport. However, where the possibility exists, managing parking facilities can be a possible "adjusting screw" for influencing the choice of transport alternatives in leisure time. The effect of managing parking spaces can be seen at the fourth facility in the sample: the "Zoo Hellabrunn" which has about the same level of public transport services as "Mensch \& Natur", but where visitors have to pay two Euros per visit for the parking space. This relatively small amount helps to increase the use of public transport by another 5\% (Fig. 10).

In special situations, it might also be possible to introduce clear additional constraints on the use of individual vehicles to increase the advantage for public transport supply. In the National Park "Bavarian Forest", the opportunity existed to measure the effects of additional constraints on private car use. The area of the National Park open to the public for walking and hiking has, for the past years, been served by buses which run on natural gas. The intensive marketing campaign for the so-called "Hedgehog-Bus" refers to the German fairy tale of the hare and the hedgehog where the slow hedgehog wins the contest against the hare by using its brain. Within the national park area two mountains, the Rachel and the Lusen, attract more or less the same target group of hikers from almost the same catchment area. The starting points of the hiking routes for the Lusen are accessible by car at any time (sufficient parking spaces at low fares are available) whereas access to the starting points for the Rachel are closed from 8 a.m. to 6 p.m. for private cars. Consequently, with the exception of handicapped persons, only the "early birds" and late afternoon visitors have access to the Rachel by car (Fig. 11).

It is perhaps unsurprising that, although there is an adequate and affordable public transport supply by HedgehogBus to both mountains - the role of public transport is much more important on the Rachel where, during daytime hours, access by car is denied. Within the framework of a student research project in 1997 , only about $20 \%$ of the hikers questioned on the summit of the "Lusen" used the bus (see Gronau et al., 1998). On the other hand, three out of four questioned on the Rachel started their tour with the bus. At the same time it has to be mentioned that since the introduction of restriction for the private car at the "Rachel", the total number of visitors has experienced a decline.

\subsection{New ways of marketing}

In addition to influencing the decision-making process by using restrictions, other, more subtle ways can also be employed. When referring to experiences in Germany, new ways of marketing are quite often very accepted and at the same time very successful methods. Apart from the traditional ways of marketing via different media and transmitting information to customers by flyers, booklet, posters, radio spots, web pages and so on, new co-operations with persons or institutions involved in the leisure and tourism market can help to strengthen the position of public transport in the leisure market. One should not underestimate their function as multipliers and disseminators of information with regards to the public transport service. On the other hand, public transport offers may increase the attractiveness of the leisure and tourism offer and as a result create additional benefit for both sides. One concrete example for a symbiotic co-operation between leisure facilities and transport organisations is the creation of a combined ticket, which includes the entrance fee for one or more leisure facilities, combined with the public transport ticket (see Gronau, 2002). If commercialised in an effective way, this kind of product provides additional advantages for the potential customer and can help to increase the number of bus users as well as the numbers of visitors at the facilities. The effects of combined-tickets can also be proven by empirical data. At the fringe of the metropolitan area of Munich a new fun and wellness bath was built a few years ago following a trend, which arose in the 1990s. The Therme Erding - as the bath is called - offers a combinedticket in co-operation with the Munich Transport Organisation. With only a small supplement to the ordinary entrance fee, visitors can use public transport within the whole metropolitan region. These tickets are sold everywhere throughout the region where it is possible to buy public transport tickets.

When questioning visitors to the Therme Erding, it came to light that only two fifths knew about this option, indicating that important deficits still exist in marketing communications for the product. On the other hand, the results among those who knew about the offer quite impressively showed the possibilities of such cross-marketing. One third of the combined-ticket users can be classified as having a quite high affinity towards the use of the private car and a third of the combined-ticket users would have had a private car available for the trip (see Gronau, 2002). This high rate of "voluntary" users is not unusual as we see from the example of the Wayfarer ticket within the Greater Manchester area, where Lurnsdon et al. (2006) established that $43 \%$ of public transport users travelling on a Wayfarer ticket had a car available. This shows that such offers can result in a noticeable shift in transport mode away from the private car.

\subsection{Long-term effects}

A further basic condition often ignored is the period of time required for newly established public transport services to achieve a significant level of customer demand. This is especially true for transport services within the context of 


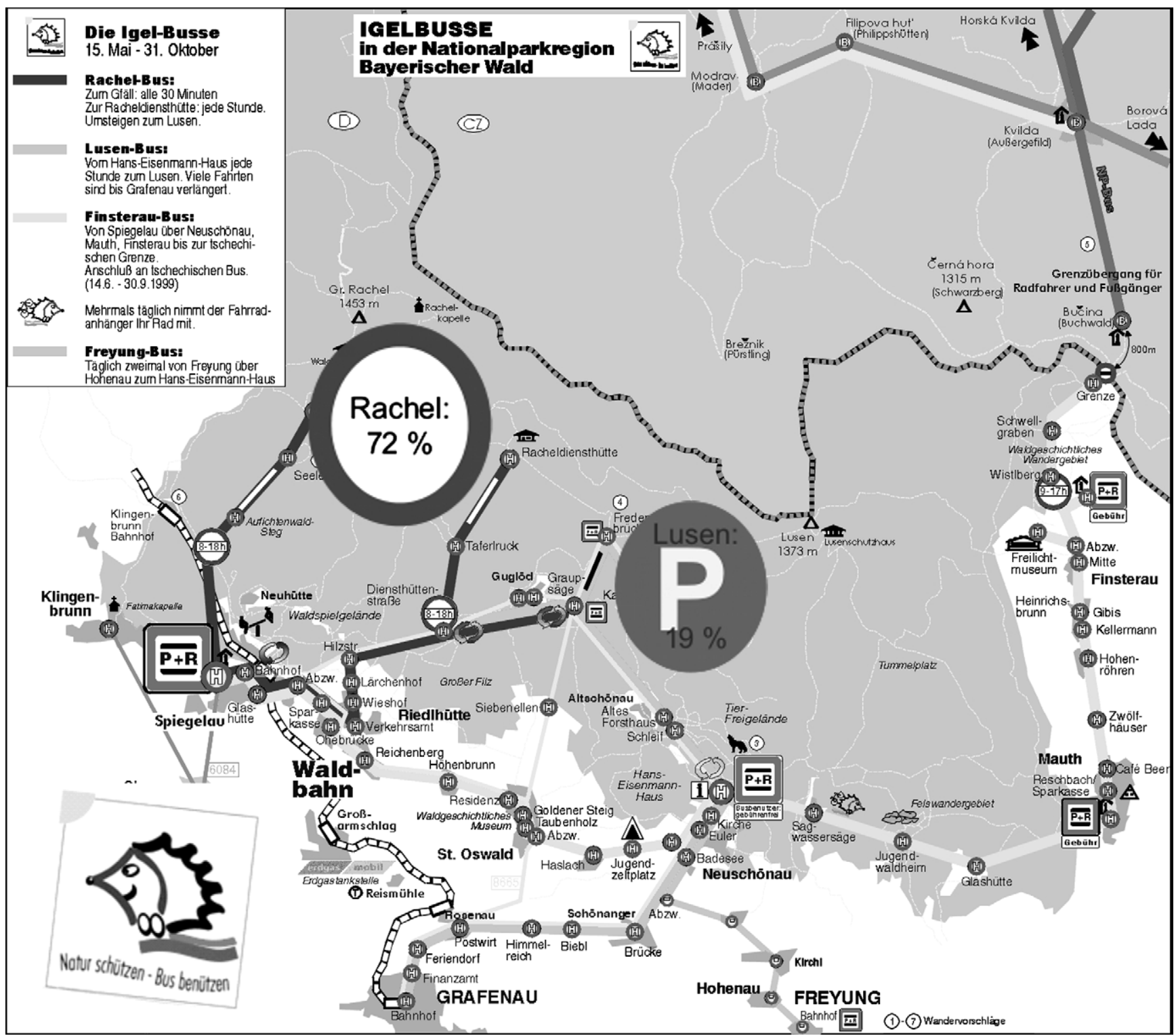

Fig. 11. The "hedgehog"-bus in the national park Bavarian forest. Source: Nationalparkverwaltung (modified)

leisure and tourism, since potential customers are not everyday users but visit the facilities or destinations only occasionally. Apart from the obvious challenge for promotional activities, this also means that it should not be expected that a new public transport service will be an overwhelming success in the first season already. In many cases, it can take several seasons for a service to become well used and to reach its saturation point in terms of possible market share. Again, this can be illustrated by an example from Germany. Fig. 12 provides figures relating to public transport provision for bicycle tourists in two low mountain ranges, the Frankenwald and the Vogelsberg region. In both cases it took about three to four years to achieve the maximum demand level for the service. Some other examples from Germany show that most organisations and local authorities become impatient if the demand level is not sufficient within the first or at least during the second year.

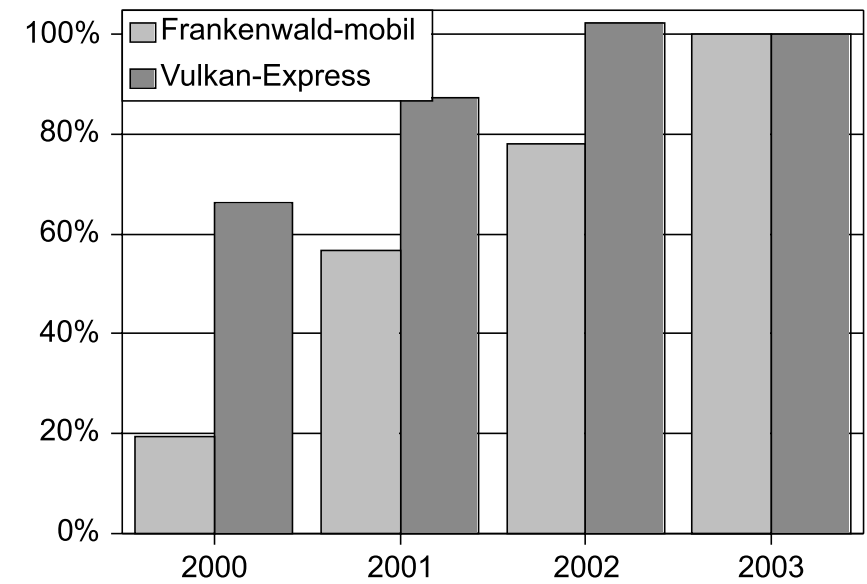

Fig. 12. Time-lag of demand reaction on a given offer. Source: own calculation based on Freitag, 2005. 


\section{Market Communication}

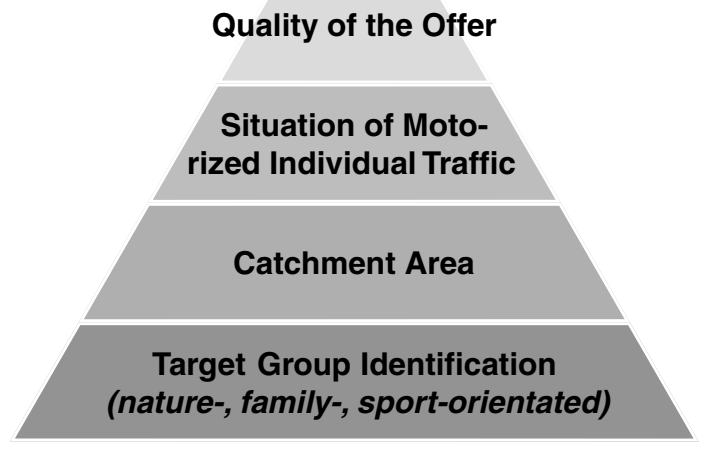

Fig. 13. Success factors for leisure and tourism transport. Source: own design.
The same appears to be true of the United Kingdom. Dickinson and Dickinson (2006), for example, stresses that funding and marketing are often too short term to generate any widespread awareness, despite the fact that this is a fundamental requirement for economic viability. Therefore, it should be stressed that, in the specific circumstances of leisure and tourism, with occasional use and an often seasonal service, the time required to achieve necessary awareness for the service is significantly higher than in different settings and a greater time period should be expected before the peak level of demand is reached.

\section{Conclusion}

In conclusion, the basic conditions for successful public transport in leisure time are, as summed up in Fig. 13. The identification of the target groups at a given destination or leisure facility is important. Only where visitors show a certain pre-disposition towards public transport use should the creation of a public transport offer should be pursued, otherwise the response potential is unlikely to be sufficient. The second area of concern is the quality of public transport within the entire catchment area of the facility. It must be ensured that the potential customer can arrive at the starting point in a convenient way. Since the degree to which a public transport offer meets a response at the demand side is also influenced by the relationship between the conditions for private car use and the level of public transport quality, the situation of the competitor should be considered as well. Only if these basic demand side conditions, and those concerning the competition situation are favourable is it worth considering the adequacy of public transport provision at the given destination. Too often this is the only aspect which is taken into consideration when trying to establish a public transport offer for leisure and tourism purposes, however as shown in this article it covers only a small part of the success factors. Once a new service is established the finishing touch is provided by a further success factor, an intensive, creative and continuous market communication.

\section{Uncited references}

Heinze (2001) and Kagermeier (2003).

\section{References}

Bamberg, S., 2004. Sozialpsychologische Handlungstheorien in der Mobilitätsforschung. In: Dalkmann, H., Lanzendorf, M., Scheiner, J. (Eds.), Verkehrsgenese, vol. 5. Studien zur Mobilitäts- und Verkehrsforschung, Mannheim, pp. 51-70.

BMVBW (Bundesministerium für Verkehr, Bau- und Wohnungswesen), 2003. Verkehr in Zahlen 2003/2004, Berlin.

Dickinson, J.E., Dickinson, J.A., 2006. Local Transport and Social Representations: Challenging the Assumptions for Sustainable Tourism. Journal of Sustainable Tourism 14 (2), 192-208.

Fastenmeier, W., Gstalter, H., Lehnig, U., 2001. Subjektiver Freizeitbegriff und Mobilitätsmuster. Ergebnisse einer bundesweiten Haushaltsbefragung, vol. 1. Berichte aus dem Institut mensch-verkehr-umwelt, München.

Freitag, E., 2005. Bedeutung und Chancen von Freizeitverkehrsangeboten des ÖPNV - dargestellt am Beispiel von Fahrradbuslinien in Deutschland, vol. 13. Studien zur Mobilitäts- und Verkehrsforschung, Mannheim).

Freitag, E., Kagermeier, A., 2002. Multiplex-Kinos als neues Angebotselement im Freizeitmarkt. In: Steinecke, A. (Ed.), Tourismusforschung in Nordrhein-Westfalen: Ergebnisse - Projekte - Perspektiven. Paderborner Geographische Studien zu Tourismusforschung, Paderborn, pp. $43-55$.

Gärling, T., Gillholm, R., Gärling, A., 1998. Re-introducing attitude theory in travel behaviour research: The validity of an interactive interview procedure to predict car use. Transportation 25, 147-167.

Gather, M., Kagermeier, A., 2002. Freizeitverkehrs als Gegenstand der Mobilitätsforschung. In: Gather, M., Kagermeier, A. (Eds.), Freizeitverkehr, Hintergründe, Probleme, Perspektiven, vol. 1. Studien zur Mobilitäts- und Verkehrsforschung, Mannheim, pp. 9-12.

Gronau, W., 2002. Grundlagen für ein erfolgreiches Mobilitätsmanagement an Freizeitgroßeinrichtungen. In: Gather, M., Kagermeier, A. (Eds.), Mobilitätskonzepte in Ballungsräumen, vol. 2. Studien zur Mobilitäts- und Verkehrsforschung, Mannheim, pp. 171-182.

Gronau, W., 2005. Freizeitmobilität und Freizeitstile. Ein praxisorientierter Ansatz zur Modellierung des Verkehrsmittelwahlverhaltens an Freizeitgroßeinrichtungen, vol. 9. Studien zur Mobilitäts- und Verkehrsforschung, Mannheim.

Gronau, W. et al., 1998. Möglichkeiten verkehrsgestaltender Maßnahmen im Nationalpark Bayerischer Wald. In: Popp, H., Kagermeier, A. (Eds.), Akzeptanz der Erweiterung des Nationalparks Bayerischer Wald. Unpublished results of fieldwork done by students of the Department of Geography Technische Universität München, München, pp. 158-226.

Gstalter, H., 2003. Thesen und Argumente zu den häufigsten Behauptungen zur Freizeitmobilität. In: Hautzinger, H. (Ed.), Freizeitmobilitätsforschung - Theoretische und methodische Ansätze, vol. 4. Studien zur Mobilitäts- und Verkehrsforschung, Mannheim, pp. 105-118.

Heath, Y., Gifford, R., 2002. Extending the theory of planned behaviour: predicting the use of public transport. Journal of Applied Social Psychology 32 (10), 2154-2189.

Heinze, G.W., 2001. Landesentwicklung durch Freizeitverkehr. Raumforschung und Raumordnung 59 (4), 249-263.

Heinze G.W., Kill, H., 1997. Freizeit und Mobilität Neue Lösungen im Freizeitverkehr. Hannover.

Hunecke, M., Blöbaum, A., Matthies, E., Höger, R., 2001. Responsibility and environment. Ecological norm orientation and external factors in the domain of travel mode choice behaviour. Environment and Behaviour 33 (6), 830-852. 
Kagermeier, A., 2002. Folgen konsumorientierter Freizeitgroßeinrichtungen für Freizeitmobilität und Freizeitverhalten. In: Gather, M., Kagermeier, A. (Eds.), Freizeitmobilität: Hintergründe, Probleme, Perspektiven, vol. 1. Studien zur Mobilitäts- und Verkehrsforschung, Mannheim, pp. 119-140.

Kagermeier, A., 2003. Freizeit- und Urlaubsverkehr: Strukturen- Probleme- Lösungsansätze. In: Becker, Ch., Hopfinger, H., Steinecke, A. (Eds.), Geographie der Freizeit und des Tourismus. Bilanz und Ausblick, München/Wien, pp. 259-272.
Lanzendorf, M., 2001. Freizeitmobilität. Unterwegs in Sachen sozial ökologischer Mobilitätsforschung, vol. 56. Materialien zur Fremdenverkehrsgeographie, Trier.

Lurnsdon, L., Downward, P., Rhoden, S., 2006. Transport for Tourism: Can Public Transport Encourage a Modal shift in the Day Visitor Market? Journal of Sustainable Tourism 14 (2), 139-156.

Paulley, N.R., Balcombe, R., Mackett, H., Titheridge, H., Preston, M., Wardman, M., Shires, J., White, P., 2006. The effect of fares, quality of service, income and car ownership. Transport Policy 13 (4), 295-306. 